\title{
A new species of Stipbropus (Aranei: Thomisidae) from China and first documentation of myrmecophily in this genus
}

\section{Новый вид пауков рода Stiphropus (Aranei: Thomisidae) из Китая и первое подтверждение мирмекофилии в этом роде}

\author{
Gui-Qiang Huang ${ }^{*}$, Ye-Jie Lin ${ }^{2}$ \\ Гуй-Џян Хуан, Е-Цзе Аинь
}

\author{
${ }^{1}$ School of Biological Science and Technology, Liupanshui Normal University, Liupanshui 553004, Guizhou, China. E-mail: \\ hgqnasa@163.com \\ ${ }^{2}$ Institute of Zoology, Chinese Academy of Sciences, Beijing 100101, China. E-mail: linyejie15@gmail.com \\ * Corresponding author
}

KEY WORDS: Asia, Araneae, crab spiders, Stiphropodinae, biology, Guangdong.

КЛЮЧЕВЫЕ СЛОВА: Азия, Araneae, пауки-бокоходы, Stiphropodinae, биология, Гуандун.

ABSTRACT. Stiphropus myrmecophilus sp.n. is described from Southern China based on both sexes, and the ecology of the new species is also discussed. Myrmecophily in this genus is described for the first time.

How to cite this article: Huang Gui-Qiang, Lin YeJie. 2020. A new species of Stiphropus (Aranei: Thomisidae) from China and first documentation of myrmecophily in this genus // Arthropoda Selecta. Vol.29. No.2. P.257-261. doi: 10.15298/arthsel. 29.2.12

РЕЗЮМЕ. ОПисан новый вид пауков-бокоходов Stiphropus myrmecophilus sp.n. из Южного Китая. Обсуждается его биология. Впервые зарегистрирована мирмикофолия в роде Stiphropus.

\section{Introduction}

Stiphropus Gerstäcker, 1873 is a relatively small genus with 20 species, 12 of which are distributed in Africa and eight in Asia [WSC, 2019]. Studies of Asian Stiphropus spp. have mainly focused on species distributed in a limited region, except that of Ono [1980] who revised six species of the genus from Asia and summarized their distribution data. Studies of Chinese Stiphropus are very scarce, and only two species, $S$. ocellatus Thorell, 1887 (China: Guangxi, Myanmar and Vietnam) and S. falciformus Yang, Zhu et Song, 2006 (China: Yunnan), were known from China [WSC, 2019] prior to this study.

While surveying spiders from Guandong, we found a new species of Stiphropus that is closely allied with the ant species Tetramorium insolens (Smith, 1861). The goal of this paper is to provide a description of the new species and brief notes on its natural history.
Materials and methods

The materials examined for this study are deposited in the following institutions: BMNH - Natural History Museum, London, United Kingdom; IZCAS - Institute of Zoology, Chinese Academy of Sciences, Beijing, China; LPSNU - School of Biological Science and Technology, Liupanshui Normal University, Liupanshui, China; SNUC - Insect Collection of Shanghai Normal University, Shanghai, China.

Specimens were preserved in $80 \%$ alcohol. Examination, photography and measurements were performed using a Leica M205A stereomicroscope equipped with a Leica DFC550 camera and LAS software (Ver. 4.6). Male palp photomicroscopy images were taken with an Olympus C7070 zoom digital camera (7.1 megapixels). Photos were stacked with Helicon Focus (Version 6.7.1) and processed in Adobe Photoshop CC 2018. Eye sizes are measured as the maximum diameter from either the dorsal or frontal view. The terminology used in the text and figures follows Ono [1988]. Distribution maps were generated using ArcMap software (Version 10.4). All measurements are in millimeters.

Abbreviations used in the text as following: ALE anterior lateral eye; AME - anterior median eye; CD copulatory duct; CO - copulatory opening; DTA - dorsal tibial apophysis; E - embolus; FD - fertilization duct; MOA - median ocular area; PLE - posterior lateral eye; PME - posterior median eye; $\mathrm{S}$ - spermatheca; Tu tutaculum; VTA — ventral tibial apophysis.

\section{Taxonomy}

\section{Genus Stiphropus Gerstaecker 1873}

Stiphropus myrmecophilus sp.n. Figs 1A-D, F-J, 2A-I, 3.

TYPE MATERIAL. Holotype $\sigma^{7}$ and allotype $q$ (IZCASAr40350-Ar40351), CHINA: Guangdong Province, Maoming City, Huazhou County, Tongqing Town, Dacha Village, $21^{\circ} 36^{\prime} 05.5^{\prime \prime} \mathrm{N}$, 

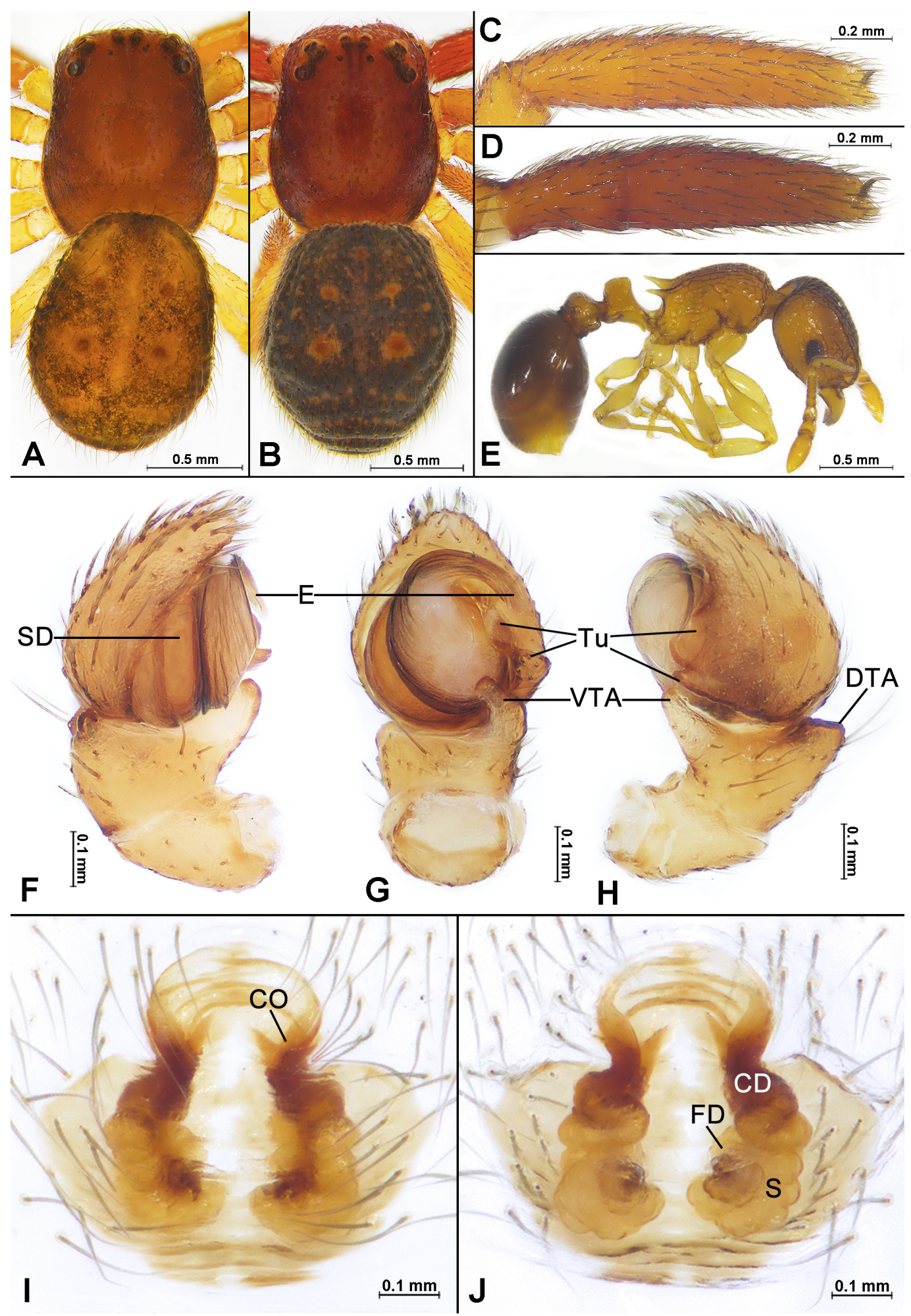

Fig. 1. Stiphropus myrmecophilus sp.n., holotype $\mathrm{O}^{7}(\mathrm{~A}, \mathrm{C}, \mathrm{F}-\mathrm{H})$ and paratype + (B, D, I-J). A-B -habitus, dorsal; C-D metatarsus and tarsus of leg I; E - host ant Tetramorium insolens; F-H - left male palp, prolateral ventral and retrolateral; I-J epigyne, ventral and dorsal. Abbreviations: CD — copulatory duct; CO — copulatory opening; DTA — dorsal tibial apophysis; E embolus; FD — fertilization duct; $\mathrm{S}$ - spermatheca; Tu — tutaculum; VTA — ventral tibial apophysis.

Рис. 1. Stiphropus myrmecophilus sp.n., голотип О7 (А, С, F-H) и паратип 9 (B, D, I-J). A-B - габитус, сверху; C-D предлапка и лапка I; E - муравей-хозяин Tetramorium insolens; F-H - пальпа самца, пролатерально, вентрально и ретролатерально; I-J - эпигина, снизу и сверху. Сокращения: CD - копулятивный канал; CO — копулятивное отвесртие; DTA дорзальный отросток голени; Е — эмболюс; FD — оплодотворительный канал; S — рецептакула; Тu — тутакулюм; VTA — вентральный отросток голени. 


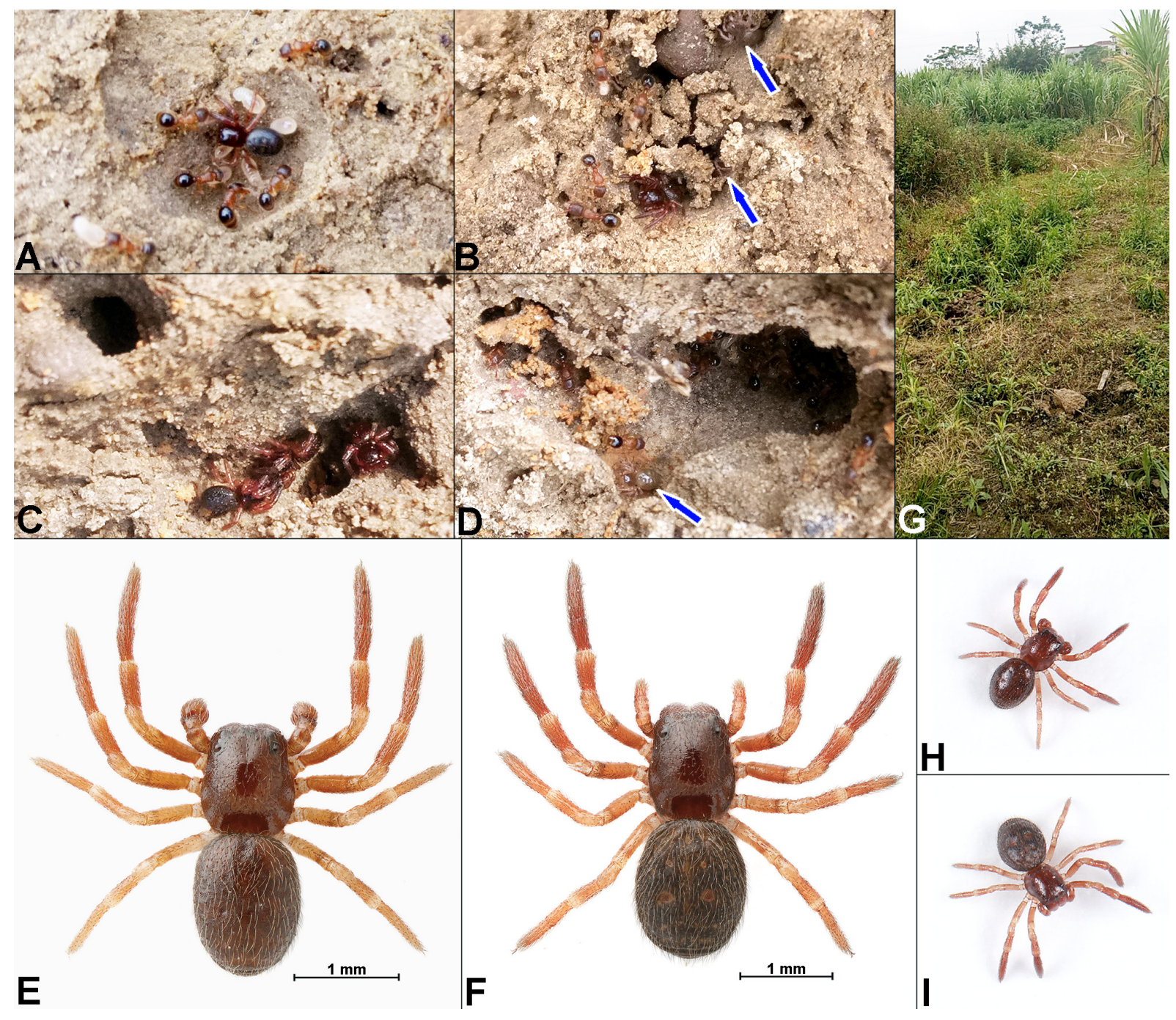

Fig. 2. Stiphropus myrmecophilus sp.n. A - female in the nursery of a Tetramorium insolens nest; B - adult (male) and juveniles (blue arrows) with associated ants; $\mathrm{C}$ - adult spiders living together in an ant nest; D - a juvenile (blue arrow) in an ant nest; $\mathrm{E}, \mathrm{H}-$ live male; F, I — live female; G — habitat of type locality. (A-D, G photographed by Feng He; E-F photographed by Ri-Xin Jiang).

Рис. 2. Stiphropus myrmecophilus sp.n. А - самка в выводковой камере в гнезде Tetramorium insolens; В - самец и ювенильные особи (голубые стрелки) вместе с муравьём-хозяином; С - взрослые пауки живущие совместно в муравейнике; D ювенильные пауки (голубая стрелка) в муравейнике; Е, Н - самец; F, I - самка; G - биотоп в котором собраны пауки; H (A-D, G фото Фен Хэ; Е-F фото Жи-Синь Цзян).

$110^{\circ} 39^{\prime} 51.1^{\prime \prime} \mathrm{E}, 10 \mathrm{~m}$, meadow, ant nest, 30.XII.2017, Feng He leg. Paratypes: $10^{7} 1$ क (SNUC), $10^{7} 3$ 우 (BMNH), 2 क (LPSNU), same data as for holotype; $2 O^{7} 0^{7} 6$ 우 (IZCAS-Ar40352-40359), same data as holotype, but 14.X.2017.

ETYMOLOGY. The specific name comes from Greek "myrmeco-" (ant) and "-philus" (beloved), refers to this species living in ant nests.

DIAGNOSIS. The new species is similar to $S$. falciformus Yang, Zhu et Song, 2006 by the shape of the ventral tibial apophysis and cymbium, as well as the location of the copulatory openings and the arrangement of the copulatory ducts in the epigyne. However, S. myrmecophilus sp.n. can be distinguished from $S$. falciformus by having the tip of the ventral tibial apophysis sub-truncated (Fig. 1G) (vs. rounded, fig. 1C in Yang et al. [2006]) and the distal half of the ventral tibial apophysis constricted (Fig. 1G) (vs. expanded, then constricted, fig. 1C in Yang et al. [2006]); the dorsal tibial apophysis is not strongly extended, but wide and subtriangular distally (Fig. 1H) (vs. strongly extended, thin and spiniform distally, fig 1D in Yang et al. [2006]); cymbium with a sub-triangular tutaculum adjacent to flake-like tutaculum in retrolateral view (Figs 1H) (vs. sub-hooked, 1D in Yang et al. [2006]); the tip of embolus (Fig 1G) rounded (bevel in S. falciformus, fig 1C in Yang et al. [2006]). Vulva sub-oval ( $v s$. sub-triangular, figs $2-3$ in Li et al. [2009]); proximal parts of the copulatory ducts wide (compared to the space between the copulatory openings, figs $1 \mathrm{I}-1 \mathrm{~J})(v s$. narrow, figs 2-3 in Li et al. [2009]); the wrinkled anterior hood narrow (compared to the width between the copulatory openings, figs 1I-1J) (vs. narrow, figs 2-3 in Li et al. [2009]). Leg formula 1243 (2143 in S. falciformus).

DESCRIPTION. Male holotype (Figs 1A,C, 2B,E,H). Total length 2.16. Carapace 1.10 long, 0.89 wide; opisthosoma 1.21 long, 0.95 wide. Carapace red-brown, covered 
with long sparse brown setae, glabrous posteriorly. Eye sizes and interdistances: AME 0.05, ALE 0.08, PME 0.01, PLE 0.05, AME-AME 0.08, AME-ALE 0.13, AME-PME 0.17, ALE-PLE 0.10, PME-PME 0.18, PME-PLE 0.17; MOA 0.14 long, eye area anterior width 0.17 , eye area posterior width 0.20 . Clypeus height 0.08 . Chelicerae with 7 promarginal peg-like teeth. Endites yellow, 3 times longer than wide. Labium yellowish-brown. Sternum yellow. Legs orange-brown, covered with plumose setae, more obvious in metatarsi and tarsi (Fig. 1C). Opisthosoma orange-brown, covered with long, sparse brown setae. Leg measurements: I 2.23 (0.61, 0.67, 0.36, 0.59); II 2.19 (0.60, 0.67, 0.34, 0.58); III $1.84(0.55,0.60,0.28,0.41)$; IV $1.88(0.58,0.57,0.29$, $0.44)$.

Palp. Yellowish-brown. Tibia subequal in length with patella, with 2 apophyses (ventral and dorsal). Ventral apophysis spoon-shaped, coiling anticlockwise about $180^{\circ}$, subtruncated at distal margin, abruptly constricted at distal $1 / 3$, with a small sub-triangular projection near distal margin, the apophysis distinctly covering the posterior margin of the bulb in ventral view (Fig. 1G), retrolateral side of the apophysis covered with several setae at proximal 1/3 (Fig. 1H), dorsal tibial apophysis not strongly extended, but wide (compared to ventral apophysis), sub-triangular distally. Cymbium covered with sparse plumose setae at dorso-prolateral half, with a sub-triangular projection adjacent to the tutaculum in retrolateral view (Figs $1 \mathrm{G}-\mathrm{H}$ ). Embolus falciform, wrinkled and rounded distally in ventral view, originating from 3:30 o'clock position and its tip ending at 2:30 o'clock position (Figs 1G-H).

Female, allotype (Figs 1B-D, 2F, I). Total length 2.36. Carapace 1.12 long, 0.92 wide; opisthosoma 1.36 long, 1.04 wide. Eye sizes and interdistances: AME 0.05, ALE 0.08, PME 0.01, PLE 0.07, AME-AME 0.07, AME-ALE 0.12, AME-PME 0.15, ALE-PLE 0.10, PME-PME 0.16, PMEPLE 0.19. MOA 0.15 long, front width 0.17 , back width 0.19 . Clypeus height 0.08 . Appearance of carapace and legs as in male. Opisthosoma black brown, with some brown sub-circular spots. Leg measurements: I $2.13(0.56,0.61$, $0.33,0.63)$; II $2.12(0.57,0.62,0.32,0.61)$; III 1.72 (0.52, $0.56,0.26,0.38)$; IV $1.77(0.55,0.54,0.29,0.39)$. Epigyne (Figs 1I-J) an inverted mushroom-shape (0.55 long, 0.60 wide), raised mesally, with a transverse, sub-oval and wrinkled anterior hood, 2 gently curving copulatory openings with openings facing anteriorly and located inside fovea; copulatory openings separated by about one diameter. Copulatory ducts strongly sclerotized close to copulatory openings and slightly longer than spermathecae. Spermathecae croissant-shaped, separated by less than 1 radius. Fertilization ducts originating near mesal sides of spermathecae.

VARIATION. Intraspecific variation occurs in the ventral tibial apophysis with a small sub-triangular projection near the distal margin in some specimens, but the projection is reduced in 3 specimens.

DISTRIBUTION. China (Guangdong) (Fig. 3).

REMARKS. All specimens were collected in nests of the ant Tetramorium insolens (Smith, 1861) (Fig. 1E).

\section{Discussion}

According to Cushing [2012], spider-ant associations can be classified into three types: myrmecomorphous (spiders have close morphological and behavioral resemblance to ants), myrmecophilous (spiders usually live alongside the ants or within ant colonies),

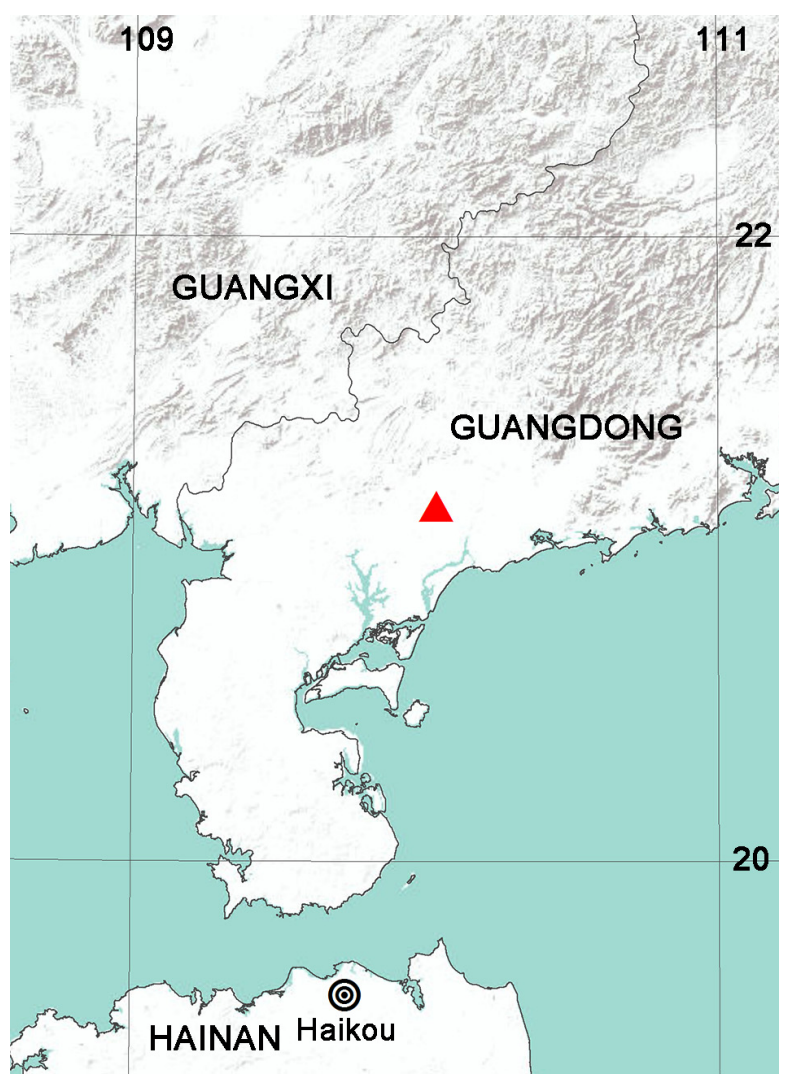

Fig. 3. Type locality of Stiphropus myrmecophilus sp.n.

Рис. 3. Типовое местообитание Stiphropus myrmecophilus sp.n.

and myrmecophagous (spiders are specialized to prey on ants). The latter two are not mutually exclusive.

S. myrmecophilus sp.n. can be classified as a myrmecophile or myrmecophage. All 21 specimens (18 adults and 3 juveniles) of $S$. myrmecophilus sp.n. were collected from 2 different ant nests. Some specimens were even found in the nursery of the ant nest (Figs 2A-D). The collectors didn't search for $S$. myrmecophilus sp.n. outside the ant nests, but evidence suggests that the discovery of $S$. myrmecophilus sp.n. in ant nests is typical.

Data on the biology of Stiphropus species are very scarce. In laboratory tests, the females of Stiphropus sp. from Ndumo Game Reserve (South Africa) frequently captured worker ants from the genera Lasius, Messor and Crematogaster [Pekar et al., 2018]. However, they also readily accepted termites, and to a lesser extent, some other arthropod prey, such as collembolans, dipterans, crickets, cockroaches and lepidopteran larvae [Pekar et al., 2018]. Unfortunately, the collectors of $S$. myrmecophilus sp.n. did not observe whether it preyed on ants (adults, pupae, eggs and larvae) or relied on other food, so we cannot determine if the new species can be classified as a myrmecophage.

Many species of Thomisidae have myrmecophagous associations with ants, which has been summarized by Cushing [2012], but none of the species in the 
genus Stiphropus has been reported to have an association with ants in a natural environment. Thus, this new species is the first documented myrmecophilous Stiphropus.

Acknowledgements. We would like to express our sincere thanks to Feng He (Maoming, Guangdong, China) and his friends for their hard field work. We are indebted to $\mathrm{Lu}$ Qiu (Chongqing, China) for providing Leica M205A stereomicroscope. We also quite appreciate Ji-Shen Wang (Xi'an, Shaanxi, China), Hao Xu (Changsha, Hunan, China), ZiWei Yin, De-Yao Zhou and Xiao-Bin Song (Shanghai, China), for their advice about animal myrmecophily and this paper. We are very grateful to Hao Ran (Hefei, Anhui, China) for identifying the associated ant, to Yuri M. Marusik (Magadan, Russia) and Elchin F. Huseynov (Baku, Azerbaijan) for the commenting early draft of our manuscript. Special thanks to Zhuo Chen (Beijing, China) and Ri-Xin Jiang (Shanghai, China) for providing invaluable specimens and taking photos. This research was supported by the Scientific Research Foundation for High-Level Talents of Liupanshui Normal University (LPSSYKYJJ201807), the Fund Project of the Education Department of Guizhou Province [Qian Education and Talent Team (2015) 72\#], the Natural Science Research Project of the Education Department of Guizhou Province (Qian Education He KY [2018] 092), the Liupanshui Science and Technology Research and Development Joint Fund Project (52020-2017-02-05), the Key Disciplines Construction Project of Liupanshui Normal University (Biological Sciences, 2015ZDZY01), the Technology Fund Project of the Science and Technology Department of Guizhou Province [Qian Science Joint J Word LKLS (2013)
04\#]. The English of the final draft was kindly checked by Sarah Crews (San Francisco, USA).

\section{References}

Cushing P.E. 2012. Spider-ant associations: an updated review of myrmecomorphy, myrmecophily, and myrmecophagy in spiders // Psyche. Vol.2012. P.1-23.

Li Z.-X., Zhou Y.-F., Yang Z.-Z. 2009. First description of the female of Stiphropus falciformus (Araneae: Thomisidae) // Acta Arachnologica. Vol.58. No.2. P.65-66.

Ono H. 1980. Thomisidae aus dem Nepal-Himalaya. III. Das Genus Stiphropus Gerstaecker 1873, mit Revision der asiatischen Arten (Arachnida: Araneae) // Senckenbergiana biologica. Bd.61. H.1/2. S.57-76.

Ono H. 1988. A revisional study of the spider family Thomisidae (Arachnida, Araneae) of Japan. Tokyo: National Science Museum. 252 p.

Pekár S., Bočánek O., Michálek O., Petráková L., Haddad C.R., Šedo O., Zdráhal Z. 2018. Venom gland size and venom complexity - essential trophic adaptations of venomous predators: A case study using spiders // Molecular Ecology. Vol.27. No.21. P.4257-4269.

WSC 2019. World Spider Catalog (version 20.0). Natural History Museum Bern; online at: http://wsc.nmbe.ch (accessed on 9 February 2019)

Yang Z.-Z., Zhu M.-S., Song D.-X. 2006. A newly recorded genus from China and two new species of the family Thomisidae // Acta Arachnologica Sinica. Vol.15. No.2. P.65-69.

Zhu M.S., Shan Y.J. 2007. The new discovery of the female spider Stiphropus ocellatus Thorell, 1887 from China (Araneae, Thomisidae) // Acta Zootaxonomica Sinica. Vol.32. No.4. P.913914.

Responsible editor Yu.M. Marusik 